\title{
Student Washback from Tertiary Standardized English Proficiency Exit Requirements in Taiwan
}

\author{
Yi-Ching Pan, National Pingtung Institute of Commerce, Taiwan \\ Tim Newfields, Toyo University, Japan
}

\begin{abstract}
In recent decades more and more tertiary institutions around the world have adopted some sort of English proficiency exit requirements. This study explores, from students' perspectives, what washback effects have been brought about by such exit requirements. Extensive questionnaire and interview data were collected from 737 students from 8 tertiary institutions with English proficiency exit requirements and 678 students from 9 institutions without. Results suggest minor differences between the two groups of students in terms of their motivation to learn English, how they prepared for tests, and the time they reputed devoted to their English studies. Implications and directions for further research are suggested.
\end{abstract}

Tests are thought to have a significant impact on course designs and classroom practices in many east Asian countries (Qi, 2004; Cheng, 2005; Choi, 2008; Watanabe, 2004a; Chen, 2002). Shohamy (2001a, 2001b) suggests that many educational administrators and policy makers regard tests as an important for educational change. In this light, it is hardly surprising that some Asian countries have recently required tertiary-level graduates to pass English proficiency examinations, ostensibly in order to bolster their English aptitude and global market competitiveness. For instance, 41 Asian tertiary institutions now require graduates to attain a minimum score in the Test of English for International Communication (TOEIC) (IIBC, 2005, p. 7). In a similar vein, Taiwan's Ministry of Education has adopted a policy of encouraging all higher education institutions to adopt English proficiency exit requirements since 2003. According to $\mathrm{Li}$ (2003), they encourage schools to adopt one or more of the following English standardized examinations as minimum standards: (1) the General English Proficiency Test (GEPT), (2) the TOEIC, (3) the Test of English as a Foreign Language (TOEFL), (4) the College Student English Proficiency Test (CSEPT), or (4) the International English Language Testing System (IELTS). As of 2012, more than one-third of technical universities/ colleges in Taiwan followed this recommendation (Pan \& Newfields, 2012).

This paper investigates how such exit requirements have impacted Taiwan's tertiary educational framework. It focuses on non-EFL majors who are still required to study English extensively. Although this paper focuses on EFL exams, it raises concerns about policies requiring graduates to meet minimum benchmarks in other disciplines. The following questions are addressed:

1. Do English proficiency exit requirements tend to affect students' motivation to study English?

2. Do such exit requirements appear to influence the amount of time students reportedly devote to their English studies? 
3. Do English proficiency exit requirements seem to influence how students prepare for tests?

\section{Literature Review}

\section{Washback - what is it?}

Since the 1980s the term "washback" has been widely used in language teaching, testing literature, and general education. It has been described by Alderson and Wall (1993, p. 117) as "the way that tests are ... perceived to influence classroom practices, and syllabus and curriculum planning". Buck (1988) simply describes it as the many ways tests influence teaching and learning. Bachman and Palmer (1996, pp. 29-35) regard washback as a feature of a broader phenomenon described as test impact, distinguishing between micro effects on specific classrooms and macro effects on societies at large. A common trait among these researchers is that they acknowledge that test washback (or impact) is not limited to students: diverse stakeholders such as teachers, students, school administrators and other test stakeholders often change their behaviours and/or beliefs because of tests.

For the purpose of this paper, washback is understood to be the effects that test(s) have on students in terms of their in class and out-of-class study patterns. These effects are likely to be viewed as positive, negative, or inconsequential by different stakeholders. If avowed curricular goals align well with the material instructors actually teach (the so-called teaching syllabus) and what students actually wish to learn (the goal of a learner-led syllabus (Breen, 1984, pp. 47-60) as well as what is in fact tested (the test syllabus), then curricular alignment is said to take place and it is hypothesized that under such conditions washback will tend to be strong. If, on the other hand, test content does not match well with these components then washback is apt to be either ineffectual or negative. Finally, we would like to underscore if a test's intended and unintended social consequences are regarded as positive, it can be said to have "consequential validity" (Messick, 1989, 1996). However, real world consensus among all stakeholders tends to be elusive. There are many cases in which a test is considered a "success" by some stakeholders, but problematic by others.

\section{Teacher washback studies}

So far the vast majority of foreign language washback studies - such as those by Alderson and Hamp-Lyons (1996), Burrows (2001, 2004), Chen (2002), Cheng (2004, 2005), Ferman (2004), Hawkey (2006), Lam (1994), Lewkowicz and Zawadowska-Kittel (2008), Qi (2005), Saif (1999, 2006), Valazza, (2008), Watanabe (1996a, 1996b, 2004a), Wall and Horak (2006, 2008), and Wu (2008) - have focused on teacher perspectives concerning tests. Two types of claims have been made: (1) tests influence both what and how instruction occurs, (2) Tests have minor impact on teaching, especially they influence only what is taught - but not how. Let us examine each of these claims.

Tests Influence Both What and How Instruction Occurs. Alderson and HampLyons, (1996), Shohamy, (1993), and Watanabe, (1996a) suggest tests affect both how and what teachers are apt to teach, though there is considerable variance in 
how teachers react to tests. Their studies indicate that teaching beliefs, experience, and educational backgrounds appear to shape teacher behaviors and to some degree, learning outcomes.

The majority of washback studies show that teaching to the test is a common practice. For example, Green (2007), Hayes and Read (2004), and Wall and Horak (2006) found activities such as offering test-taking tips, question analysis and a de-emphasis on oral skills predominate the IELTS/TOEFL preparation classes they observed. Ferman (2004) also noted how a new Israeli EFL oral test increased the amount of time teachers spent on interview rehearsals, role-plays, and other activities to help students perform better on that exam. The emphasis on oracy in the new exam appeared to change both the content and process of instruction.

In other disciplines we can also find studies purporting tests influence instruction. Popham (1987) mentions how the math scores of first grade elementary school students in South Carolina improved as a result of test-driven instruction. Not all studies suggest such positive results. A study by Shulte, Schulte, Slate, and Brooks (2002) suggests that significant "teaching to the test" and increased teacher anxiety occurred among many elementary school teachers in Texas as a result of test-driven instructional policies.

Tests Have a Minor Impact on Teaching - They Appear to Influence What is Taught, But Not How. Cheng (2004, 2005), Green (2007), Wall and Alderson (1993), and Wall, (2005) suggest that while course content often changes because of a given test, the way teachers instruct is more impervious to change. Whatever modifications do occur in teaching behavior, Cheng (2005, p. 235) maintains, tend to be "superficial". In her view, to induce substantial teacher change teacher education is needed, not merely testing.

Some studies suggest tests do not influence significantly teaching. For example, Qi $(2004,2005,2007)$ has shown how a reputedly "communicative" test in China failed to stop traditional cramming practices. Surveying 388 teachers from 180 high schools, she found that approximately $57 \%$ of the class time was spent on test drilling, 35\% on grammar and vocabulary practice, and only $7 \%$ on communicative language use. Teacher beliefs about the need to bolster scores for this gate-keeping test and their own widespread lack of linguistic proficiency (p. 163) appear to have scuttled the avowed test goals to promote communicative teaching. In the same vein, merely a few of the 20 university instructors that $\mathrm{Li}$ (2008) surveyed indicated that they changed what or how they taught following the introduction of a new test. The test that she examined had only a minor impact on how teachers taught, but her sample size was too small to conjecture about the entire population. Unfortunately, this is true of many washback studies.

\section{Student washback studies}

In contrast to the ample (albeit mostly small-scale) teacher washback studies, student washback research is dearth. Wall (2000, p. 502) laments the paucity of research and Cheng (2008), Spratt, (2005), and Watanabe (2004b) emphasize the need to explore the impact of tests on learners. Two types of student washback claims are documented: (1) tests influence what is learned - but not bow, and (2) tests have a minimal effect on learning. Each of these claims is also briefly considered. 
Tests Influence Only What is Learned But Not How. Stoneman (2006) investigated how 655 students of in Hong Kong prepared for an exit exam. Her study revealed that over half the students were more motivated to prepare for a high-status international exam, but not for a local exam with less status. However, the methods used in preparing for both exams were similar. More than half of the students in her study said that they preferred traditional methods such as going through previous exams and/or relying on test prep books (p. 398). Stoneman's finding is consistent with Cheng's $(1998,2005)$ that tests have negligible impact on student learning strategies or exam preparation methods.

Tests Have a Minimal Effect on Student Learning. Bright and Von Randow (2004) studied how a test of English academic skills affected 18 foreign students in New Zealand. Despite knowing that their test scores would decisively impact their academic careers, low-proficiency students tended to make no effort to improve their scores. Subsequently, that test had nominal impact on the students - the majority simply ignored it.

Shih (2007) has explored the effects of an exit exam on 29 Taiwanese university students. Although 58\% $(n=17)$ of the participants considered that test important, few actually spent time preparing for it. This echoes Bright and Von Randow's point: merely knowing that a test is important isn't enough to guarantee that most people will actually study harder for it. However, like the earlier study by $\mathrm{Li}$ (2008), the small sample size of this study makes it difficult to generalize to larger populations.

In American K-12 research contexts, we can find many studies suggesting that high-stakes testing does little to facilitate student learning. For example, Klein, Hamilton, McCaffrey, and Stecher (2000) compared performance on a high-stakes Texas state exam for which the teachers and students were studying vigorously with performance on a low-stakes national exam that they were not actively studying for. The data suggests that scores on the high-stakes state exam did not correlate well with the low-stakes national exam, which reputedly measured the same skills. They pointed out how seeming "improvement" in one test may not translate as evidence of greater learning by a different test supposedly measuring the same construct.

Considering the modest amount of EFL studies on learner washback, further research is needed to investigate how tests influence student motivation and learning strategies, which is the focus of this study.

\section{Methodology}

This research consisted of two phases: a survey phase, and a structured interview phase. A stratified convenience sample of 1415 students was used for the survey phase of this study. This consisted of 737 students from 8 tertiary institutions in Taiwan with English proficiency exam exit requirements (herein referred to as ECER schools) and 678 students from 9 schools without such requirements (herein referred to as non-ECER schools). A demographic profile of these two groups appears in Table 1 . Table 2 provides further information about how these respondents have reputedly fared on various English proficiency tests. All of the respondents were Taiwanese and non-English majors. 


\begin{tabular}{|l|l|c|c|}
\hline \multirow{2}{*}{ Gender } & & Number $(n)$ & Percentage (\%) \\
\hline \multirow{2}{*}{ Major } & Male & 723 & 51.1 \\
\cline { 2 - 4 } & Female & 691 & 48.9 \\
\hline & $\begin{array}{l}\text { Business/ } \\
\text { Management }\end{array}$ & 657 & 47.4 \\
\cline { 2 - 4 } & Engineering & 431 & 31.1 \\
\hline & $\begin{array}{l}\text { Humanities } \\
\text { and Social Science }\end{array}$ & 103 & 7.4 \\
\hline \multirow{2}{*}{ Year of study } & Agriculture & 22 & 1.6 \\
\hline & Other & 172 & 12.4 \\
\hline Schools with exit & Second & 951 & 67.6 \\
\cline { 2 - 4 } & Third & 200 & 14.2 \\
\hline requirements & Fourth & 256 & 18.2 \\
\hline & Yes & 737 & 52.1 \\
\hline
\end{tabular}

Table 1: A Profile of the Survey Participants of this Study

\begin{tabular}{|l|c|c|c|c|}
\hline & \multicolumn{3}{|l|}{ ECER Students } & Non-ECER Students \\
\cline { 2 - 5 } & $n$ & $\%$ & $n$ & $\%$ \\
\hline $\begin{array}{l}\text { Taken } \\
\text { ECT }\end{array}$ & 446 & 60.8 & 297 & 44.2 \\
\hline $\begin{array}{l}\text { Not } \\
\text { taken } \\
\text { ECT }\end{array}$ & 287 & 39.2 & 375 & 55.8 \\
\hline GEPT & 182 & 53.5 & & \\
\hline CSEPT & 63 & 18.5 & 0 & 84.3 \\
\hline TOEIC & 48 & 14.1 & 17 & 0.0 \\
\hline TOEFL & 6 & 1.8 & 2 & 0.7 \\
\hline IELTS & 0 & 0.0 & 0 & 0.8 \\
\hline Other & 41 & 12.1 & 21 & 8.2 \\
\hline $\begin{array}{l}\text { Passed } \\
\text { ECT }\end{array}$ & 151 & 38.2 & 96 & 63.6 \\
\hline $\begin{array}{l}\text { Not } \\
\text { passed } \\
\text { ECT }\end{array}$ & 230 & 58.2 & 173 & 1.0 \\
\hline $\begin{array}{l}\text { Waiting } \\
\text { results }\end{array}$ & 14 & 3.5 & 3 & \\
\hline
\end{tabular}

Table 2: The Survey Participants Experience with English Certification Tests (ECT) 
For the interview phase of this study, a convenience sample of 71 respondents from the survey sample who indicated a willingness to be interviewed was employed. 38 respondents came from 8 different ECER schools and 33 came from 6 non-ECER schools. A demographic profile appears in Table 3.

\begin{tabular}{|c|c|c|c|}
\hline \multicolumn{2}{|c|}{ Respondents } & $n$ & $\%$ \\
\hline \multirow{2}{*}{ Gender } & Male & 25 & 35 \\
\hline & Female & 46 & 65 \\
\hline \multirow[t]{4}{*}{ Major } & $\begin{array}{l}\text { Business / } \\
\text { Manageme } \\
\text { nt }\end{array}$ & 37 & 52 \\
\hline & Engineering & 19 & 27 \\
\hline & Agriculture & 6 & 8 \\
\hline & Other & 9 & 13 \\
\hline \multirow{3}{*}{ Year } & Second & 28 & 39 \\
\hline & Third & 30 & 42 \\
\hline & Fourth & 13 & 19 \\
\hline \multirow[t]{2}{*}{ School type } & $\begin{array}{l}\text { ECER } \\
\text { schools }\end{array}$ & 38 & 54 \\
\hline & $\begin{array}{l}\text { Non- } \\
\text { ECER } \\
\text { schools }\end{array}$ & 33 & 46 \\
\hline \multirow[t]{2}{*}{ Passed exams? } & Yes & $\begin{array}{c}14 \\
\text { (10 at ECER schools) }\end{array}$ & 20 \\
\hline & No & 57 & 80 \\
\hline
\end{tabular}

Table 3: A profile of the Participants in the Interview Phase of this Study

\section{Instruments}

The two instruments used in this research will each be briefly described. First, a 36-item paper-and-pencil survey was employed. Second, structured interviews consisting of 11-18 focus questions were held for non-ECER and ECER students respectively.

Phase 1 Surveys. The original Chinese version of the translated survey was distributed to 800 students at 8 ECER schools and 750 students at 9 non-ECER schools. Of the 1,550 surveys distributed, 1,415 valid questionnaires were returned. Surveys with less than 2 missing items were considered valid. SPSS 12.0 was used to analyze the questionnaires, which contained two types of questions: multiple-choice questions with categorical responses and 5-point Likert scale questions with pseudo-ordinal responses. After basic descriptive statistics from this data was obtained, the 5-point Likert scale responses ranging from "strongly agree (5)" to "strongly disagree (1)" were truncated into three categories: "agree", "uncertain", and "disagree". The 5-point Likert scale frequency responses were also truncated into three categories: the "never" and "seldom" responses were lumped together into a superordinate "rarely" category; the "usually" and "always" responses were consolidated into a superordinate "frequently" category; 
and the mid-range response - "sometimes" - remained unchanged. These differences were tested for statistical significance with a Mann-Whitney U test for the pseudo-ordinal data. A chi-square test was used for the categorical MC data. A probability of less than .05 was set for the significance level. In addition, effect sizes using Cohen's $d$ for the statistically significant items were calculated to better gauge how the two groups of students varied. This should also facilitate any subsequent meta-analyses.

Phase 2 Structured Interviews. All interviews were digitally recorded, transcribed, and then analyzed according to the analytical-strategy proposed by Schmidt (2004).

\section{Results}

Let us consider the results in terms of each research question.

1. Do English Proficiency Exit Requirements Tend to Affect Students' Motivation to Study English? The Phase 1 data in Table 4 suggests that students from both types of schools varied little in terms of motivation for English study. Only one fourth of the survey items had statistically significant sub-group differences. However, the effect sizes for these three items were small $(d<0.3)$, indicating that students at schools with exit requirements tended to be only marginally more motivated to study by English than their peers.

The Phase 2 interviews suggest that there may have been increased motivation for ECER students to study English. When asked if they had experienced any positive effects as a result of the exit requirements, 14 of the 24 ECER interviewees indicated the policy motivated them to study "somewhat harder". 10 of them claimed that they were passive learners who needed external inducements such as the test requirements to compel them to study. Informant S174 commented, "Since I will not be allowed to graduate unless I pass the test, the policy has pressured me into studying English." Although 21 of the 31 student informants admitted the exit requirement policy pressured them, informant S63 felt that it brought "more encouragement than stress." In other words, students interpreted the exam pressure in varied ways. Six ECER informants expressed anxiety about graduating and candidly acknowledged they had no desire to study English because of the exit requirements, despite knowing their English levels were low. One informant (S122) also mentioned that those who couldn't pass the proficiency test were looked down upon by their peers. 


\begin{tabular}{|c|c|c|c|c|c|c|}
\hline \multirow{2}{*}{$\begin{array}{l}\text { Reputed motive for } \\
\text { studying }\end{array}$} & \multicolumn{3}{|c|}{ Students at ECER schools } & \multicolumn{3}{|c|}{ Students at non-ECER schools } \\
\hline & $N$ & $M$ & $S D$ & $N$ & $M$ & $S D$ \\
\hline $\begin{array}{l}\text { Have better } \\
\text { opportunities in } \\
\text { the future }\end{array}$ & 735 & 4.20 & .73 & 676 & 4.24 & .70 \\
\hline $\begin{array}{l}\text { Learn daily } \\
\text { English }\end{array}$ & 735 & 4.15 & .70 & 677 & 4.19 & .70 \\
\hline $\begin{array}{l}\text { Be able to } \\
\text { communicate } \\
\text { when traveling }\end{array}$ & 737 & 4.12 & .79 & 677 & 4.12 & .81 \\
\hline $\begin{array}{l}\text { Meet expectation } \\
\text { of job market }\end{array}$ & 732 & 4.11 & .72 & 676 & 4.15 & .71 \\
\hline $\begin{array}{l}\odot * \text { Prepare for } \\
\text { proficiency } \\
\text { tests / earn } \\
\text { certificates }\end{array}$ & 736 & 3.90 & .82 & 675 & 3.67 & .87 \\
\hline $\begin{array}{l}\odot * \text { Pass test to } \\
\text { graduate }\end{array}$ & 731 & 3.84 & .95 & 671 & 3.59 & .96 \\
\hline $\begin{array}{l}\text { Understand } \\
\text { English movies } \\
\text { and programs }\end{array}$ & 736 & 3.83 & .91 & 677 & 3.85 & .89 \\
\hline $\begin{array}{l}\text { Understand } \\
\text { professional } \\
\text { knowledge in } \\
\text { English }\end{array}$ & 735 & 3.75 & .85 & 676 & 3.72 & .87 \\
\hline $\begin{array}{l}\odot * \text { Enhance } \\
\text { proficiency to } \\
\text { continue on to } \\
\text { higher education }\end{array}$ & 734 & 3.63 & .88 & 677 & 3.52 & .89 \\
\hline $\begin{array}{l}\text { Fulfill parents' } \\
\text { expectations }\end{array}$ & 734 & 3.43 & 1.00 & 675 & 3.43 & 1.00 \\
\hline
\end{tabular}

Table 4. A Comparison of Students' Stated Motivation to Study English Based on the Survey SYMBOLS: $\odot$ Cohen delta effect size $\leqq 0.3 *$ Mann-Whitney U-test, statistically significant difference between the two groups of schools at $p<.05$ 
2. Do English Proficiency Exit Requirements Appear to Influence the Amount of Time Students Reputedly Devoted to Their English Studies? The survey data in Table 5 shows how much time students from both groups reported studying English per week outside of class when school was in session. Note that 8 out of the 1415 respondents ( 5 of whom were from ECER schools and 3 of whom were from non-ECER schools) did not respond to this question.

\begin{tabular}{|c|c|c|c|c|c|}
\hline & $\begin{array}{c}\text { Only before } \\
\text { tests }\end{array}$ & $\begin{array}{c}\text { Under } 1 \mathrm{hr} \text {. } \\
\text { per week }\end{array}$ & $\begin{array}{l}\text { 1-3 hrs. } \\
\text { per week }\end{array}$ & $\begin{array}{c}\text { Over } 3 \text { hrs. } \\
\text { per week }\end{array}$ & Total \\
\hline $\begin{array}{l}\text { Students at } \\
\text { ECER } \\
\text { schools }\end{array}$ & $\begin{array}{l}161 \\
(22 \% \text { of } \\
\text { ECER })\end{array}$ & $\begin{array}{l}215 \\
(29 \% \text { of } \\
\text { ECER) }\end{array}$ & $\begin{array}{l}292 \\
(40 \% \text { of } \\
\text { ECER) }\end{array}$ & $\begin{array}{l}65 \\
(8 \% \text { of } \\
\text { ECER) }\end{array}$ & $\begin{array}{l}733 \\
(52 \% \text { of } \\
\text { total) }\end{array}$ \\
\hline $\begin{array}{l}\text { Students at } \\
\text { non-ECER } \\
\text { schools }\end{array}$ & $\begin{array}{l}221 \\
(33 \% \text { of } \\
\text { non-ECER) }\end{array}$ & $\begin{array}{l}224 \\
(33 \% \text { of } \\
\text { non-ECER) }\end{array}$ & $\begin{array}{l}190 \\
(28 \% \text { of } \\
\text { non-ECER) }\end{array}$ & $\begin{array}{l}39 \\
(5 \% \text { of } \\
\text { ECER) }\end{array}$ & $\begin{array}{l}674 \\
(48 \% \text { of } \\
\text { total) }\end{array}$ \\
\hline $\begin{array}{l}\text { Total } \\
\text { Students }\end{array}$ & $382(27 \%)$ & $439(31 \%)$ & $482(34 \%)$ & $104(7 \%)$ & $\begin{array}{l}1407 \\
(100 \%)\end{array}$ \\
\hline
\end{tabular}

Table 5. Student Self-reports of Time Outside of Class Allocated to English Study when School Was in Session

$\mathrm{X}^{2}=35.492 ; \mathrm{df}=3, p=.000, d=0.2$

Around $48 \%$ of the ECER respondents reported spending one hour or more on English each week, compared to merely 33\% of their counterparts. Although there was a statistically significant difference between these two groups, the effect size was small $(d=0.2)$. This suggests that the difference between both groups regarding time investment in English study was minimal: $53 \%$ of the response distributions overlapped.

Moreover, one third $(n=13)$ of the 38 interview respondents at ECER schools said that they used their school's language labs or websites for English study. In contrast, only one of their 33 counterparts mentioned doing this. In other words, students at ECER schools were far more likely to use their school's CALL facilities than their peers.

3. Do English Proficiency Exit Requirements Seem to Influence the Methods Students Employ for Test Preparation? The Phase 1 data in Table 6 compares how the two groups of students reported preparing for their English exams. More than half of the students in both groups reported using traditional test preparation methods such as text reading, rote memorization, and practicing grammar exercises. 


\begin{tabular}{|c|c|c|c|c|c|c|}
\hline \multirow{2}{*}{$\begin{array}{l}\text { Exam Prep } \\
\text { Strategies }\end{array}$} & \multicolumn{3}{|c|}{ Students at ECER schools } & \multicolumn{3}{|c|}{ Students at non-ECER schools } \\
\hline & $N$ & $\mathrm{M}$ & SD & $N$ & M & SD \\
\hline $\begin{array}{l}\text { Memorize } \\
\text { vocabulary / } \\
\text { phrases }\end{array}$ & 734 & 3.76 & 0.93 & 677 & 3.80 & 0.99 \\
\hline $\begin{array}{l}* \text { Read } \\
\text { textbooks }\end{array}$ & 734 & 3.65 & 0.96 & 675 & 3.75 & 1.00 \\
\hline * Take notes & 737 & 3.55 & 0.99 & 676 & 3.72 & 0.95 \\
\hline $\begin{array}{l}\text { Practice text } \\
\text { exercises }\end{array}$ & 736 & 3.50 & 0.98 & 675 & 3.59 & 1.01 \\
\hline $\begin{array}{l}\text { Practice } \\
\text { grammar }\end{array}$ & 734 & 3.17 & 0.99 & 675 & 3.10 & 1.03 \\
\hline $\begin{array}{l}\text { * Practice } \\
\text { past / mock } \\
\text { exams }\end{array}$ & 736 & 3.14 & 1.04 & 675 & 3.02 & 1.08 \\
\hline $\begin{array}{l}\text { Practice } \\
\text { sentence and } \\
\text { essay writing }\end{array}$ & 735 & 2.87 & 1.04 & 676 & 2.80 & 1.07 \\
\hline $\begin{array}{l}* \text { Listen to } \\
\text { audio of text } \\
\text { or radio }\end{array}$ & 733 & 2.55 & 1.12 & 675 & 2.35 & 1.07 \\
\hline $\begin{array}{l}\text { (0) Practice } \\
\text { online test } \\
\text { questions }\end{array}$ & 730 & 2.37 & 1.00 & 671 & 1.84 & 0.97 \\
\hline $\begin{array}{l}\text { Take extra } \\
\text { lessons at } \\
\text { cram schools }\end{array}$ & 733 & 2.25 & 1.12 & 676 & 2.18 & 1.10 \\
\hline $\begin{array}{l}\text { * Practice oral } \\
\text { skills with } \\
\text { classmates }\end{array}$ & 737 & 2.05 & 0.86 & 672 & 1.94 & 0.88 \\
\hline $\begin{array}{l}\text { * Practice oral } \\
\text { skills with } \\
\text { teachers }\end{array}$ & 734 & 2.03 & 0.87 & 677 & 1.93 & 0.86 \\
\hline
\end{tabular}

Table 6. How Two Groups of Taiwanese University Students Reported Preparing for English Exams According to the Survey

SYMBOLS: *Mann-Whitney U-test, statistically significant difference between the two groups of schools at $p<.05$ (O) Moderate effect size $(d=0.5)$, all other effect sizes were small $d<0.3$

Although there were six statistically significant differences between the two groups, only one had a moderate effect size $(d=0.5)$. Students at schools with exit requirements reputedly did more test-related practice than their counterparts. All other effect sizes were slight $(d<0.3)$.

The Phase 2 interviews suggest a different picture. When asked if they were aware what educational resources their schools provided for students to prepare for certification tests, 11 ECER students mentioned utilizing their school's CALL facilities, compared to only 4 of their counterparts. In addition, when asked if they wanted more test preparation class instruction, nearly three times more students at ECER schools $(n=20)$ voiced a desire for more test- 
cramming courses than did their counterparts $(n=7)$. Given the fact that only one quarter of the 38 ECER examinees had already passed the exit exams, it seems understandable that so many of these students wished for more test-prep instruction.

\section{Discussion}

In Deci and Ryan's (1985) model of motivation, autonomous learning is considered an indicator of motivation, and such learning is thought to occur when learners perceive the value of acquiring new knowledge. The data from this research suggests that few students perceived the value of the educational activities connected with their English test preparation. It is therefore hardly surprising that participation in extensive voluntary autonomous learning was so sparse. For this population at least, it appears the English certification exit requirements did not enhance student motivation to a large extent. In addition, Dickinson (1995) claims that successful learning and enhanced motivation occur only if learners take "responsibility for their own learning and gain ... control over the learning process" (p. 174). However, considering the avowed desire of many interviewees for test-prep instruction, it appears many students in this study were seeking the sort of teacher-centered, taskmaster-based instruction that they had in high school. In other words, few students expressed an interest in achieving learner autonomy.

Data from the first two phases of this study showed that students tended to focus more on reading and listening than on writing and speaking skills. As a consequence, foreign language production skills appeared to be underdeveloped. This is not surprising because the majority of informants did not believe they would actually need to use the language skills supposedly being taught to any significant degree in their immediate future.

Considering all of this, many students' extrinsic motivation may have marginally increased because of the new exit requirements. However, their intrinsic motivation did not appear to develop accordingly. As most readers probably know, extrinsic motivation refers to a desire to learn things to fulfill external goals such as passing a test, obtaining a job, or earning more. By contrast, intrinsic motivation occurs when learning becomes its own reward (Deci, 1971).

It is often claimed that learning is more likely to be successful or effective if intrinsic motivation is high, especially in the long term (Brown, 2001; Gardner \& Lambert, 1972; Poret, 2007). Harlen and Crick (2003) remind us, however, that motivation is complex and associated with concepts such as self-esteem, selfefficacy, effort, and self-regulation (p. 169). This is not something a mere test can engender. Indeed, this might explain why gains in ECER students' avowed motivation to study was nominal, and why changes in the amount of time they reputedly studied were also so modest.

Gardner and MacIntyre (1993) suggest that motivation consists of three components: (1) a desire to achieve a goal, (2) an effort towards that direction, and (3) a feeling of fulfilment when a task is completed (p. 2). Though mandating English proficiency exams may have enhanced the first two components, there is no evidence suggesting that any sense of task fulfilment was increased considering the low pass rate of students at ECER schools (see Tables 2 and 3). Thus, the effect of the English certification exit requirements on student motivation appears to be partial at best.

The slighter higher desire to pass the proficiency tests reported by many 
students at ECER schools might be why they spent marginally more time on English study. However, this negligible time difference was not enough to translate into significantly higher scores. The evidence from this research makes it clear that the test requirements did not lead to a noteworthy amount of "studying for the test". Moreover, old habits of traditional, non-communicative study seemed to remain entrenched.

This research confirms the contention of other washback studies that tests are not a panacea that will always succeed in promoting student learning. Because of the weak impact perceived in this context, policymakers and administrators need to understand that any attempts to drive reform or enhance learning outcomes through the imposition of tests are unlikely to succeed in the absence of consensus within the wider society about the value or quality of the test and the usefulness of the skills tested. Top-down testing policies, developed without due consultation with all relevant score users, may be ineffective, may produce effects that are quite different from what is intended, or may result in insignificant effects. Therefore, it is suggested that policymakers (administrators) take into consideration various stakeholders' opinions before instituting a testdriven policy, and evaluate test effects after implementation to investigate whether the intended positive effects have, in fact, been attained or whether the policy has elicited more negative effects or no effects at all.

\section{Conclusions}

Let us now briefly summarize the main points of this study, acknowledge some of its limitations, and suggest avenues for further research. Three findings have been suggested by this study. Each is briefly summarized.

Motivation for English Study. More than half of the ECER students in the Phase 1 indicated that they did not believe that the EFL exit exams enhanced their incentive to study. However, nearly $65 \%$ of the 38 Phase 2 ECER informants indicated that the tests pushed them to study to some extent. This suggests that the exit exams probably had inconclusive effects on motivation.

Time Allocated to English Study. Although Phase 1 and 2 ECER informants indicated they spent slightly more time studying than their peers, $51 \%$ of the survey respondents claimed to spend less than an hour of English study per week. This suggests that the exit exams did not significantly affect the amount of time most respondents studied.

Methods Adopted to Study English and Prepare for English Tests. Both groups tended to rely on traditional test cramming methods. However, nearly $10 \%$ more students at ECER schools appeared to use a somewhat broader variety of study approaches than their counterparts. In other words, they claimed to spend more time reading magazines, listening to English CDs or radios or practicing conversations than their peers. Nearly half ECER students claimed that they often or sometimes use their school self-access centers and test practice websites while around one fifth of their counterparts made such a claim (See Table 6). These two findings seems to indicate that the exit requirements may have encouraged a modest amount of learning through communicatively-oriented and test-prep approaches. 


\section{Limitations and further avenues to explore}

This study has three salient limitations and should serve suggestions for further research. First, its focus is limited to a policy of mandating EFL proficiency in a Taiwanese tertiary context among non-English majors. Whether or not the patterns in this study would generalize to respondents with different educational backgrounds or fields other than English is an open question. Future studies should explore how exit exam policies appear to impact test stakeholders in different learning environments.

Second, this paper offers a glimpse of how one group of students have responded to an educational policy at only one point in time. This study was conducted at a period when many institutions in Taiwan were eager to eager to adopt the government's EFL exit exam policy. A longitudinal study would surely offer a clearer picture of the long term effect of this exit exam policy. Similar longitudinal studies should also be conducted at schools with proficiency exams requirements in other disciplines such as math or computer literacy.

Third, this paper has relied on self-reported student data. As Nisbett and Wilson (1977, pp. 231-259) and Yu (2010) point out, such information is easily prone to expectancy bias. Subsequent research should include more classroom observational data and seek to corroborate student information with other data sources from teachers and school administrators. This should allow researchers to get a more accurate and dynamic picture of how washback patterns are perceived by different test stakeholders.

\section{References}

Alderson, C., \& Hamp-Lyons, L. (1996). TOEFL preparation courses: A study of washback. Language Testing, 13 (3), 280-297. doi: 10.1177/026553229601300304.

Alderson, C., \& Wall, D. (1993). Does washback exist? Applied Linguistics, 14, 115-129.

Bachman, L. F., \& Palmer, A. S. (1996). Language testing in practice. Oxford University Press.

Breen, M. P. (1984). Process syllabuses for the language classroom. In C. J. Brumfit, (Ed.) General English Syllabus Design (pp. 47-60). Elmsford, NY: Pergamon Press \& the British Council.

Bright, C., \& Von Randow, J. (2004, September). Tracking language test consequences: The student perspective. Paper presented at the Ninth National Conference on Community Languages and English for Speakers of Other Languages (CLESOL 2004), Christchurch.

Brown, J. D. (2001). Teaching by principles: An interaction approach to language acquisition. Canadian Journal of Psychology, 13, 266-272.

Buck, G. (1988). Testing listening comprehension in Japanese university entrance examination. JALT Journal, 10, 15-42.

Burrows, C. (2001). Searching for washback: The impact of assessment in the certificate in spoken and written English. In G. Brindley \& C. Burrows (Eds.), Studies in immigrant English language assessment (Vol. 2) (pp. 95-187). Sydney, Australia: National Center for English Language Teaching and Research.

Burrows, C. (2004). Washback in classroom-based assessment: A study of the washback effect in the Australian adult migrant English program. In L. Cheng, Y. Watanabe \& A.Curtis (Eds.), Washback in language testing: Research contexts and methods (pp. 113-128). Mahwah, NJ: Lawrence Erlbaum.

Chen, L. (2002). Taiwanese junior high school English teachers' perceptions of the washback effect of the basic competence test in English. Unpublished doctoral dissertation, Ohio State University.

Cheng, L. (1998). Impact of a public English examination change on students' perceptions 
and attitudes toward their English learning. Studies in Educational Evaluation, 24 (3), 279-301.

Cheng, L. (2004). The washback effect of a public examination change on teachers' perceptions toward their classroom teaching. In L. Cheng, Y. Watanabe \& A. Curtis (Eds.), Washback in language testing: Research contexts and methods (pp. 147-170). Mahwah, NJ: Lawrence Erlbaum.

Cheng, L. (2005). Changing language teaching through language testing: A washback study. Cambridge University Press.

Cheng, L. (2008). Washback, impact and consequences. In E. Shohamy \& N. H. Hornberger (Eds.), Encyclopedia of Language and Education (2 ${ }^{\text {nd }}$ ed., Vol. 7) (pp. 349-364). New York; London: Springer.

Choi, I. C. (2008). The impact of EFL testing on EFL education in Korea. Language Testing, 25 (1). 39-62. doi: 10.1177/0265532207083744.

Deci, E. L., \& Ryan, R. M. (1985). Intrinsic motivation and self-determination in human behavior. New York: Plenum.

Dickinson, L. (1995). Autonomy and motivation: a literature review. System, 23(2), 165-174.

Ferman, I. (2004). The washback of an EFL national oral matriculation test to teaching and learning. In L. Cheng, Y. Watanabe \& A. Curtis (Eds.), Washback in language testing: Research contexts and methods (pp. 191-210). Mahwah, NJ: Lawrence Erlbaum.

Gardner, R. C. \& Lambert, E. (1972). Attitudes and motivation in second language learning. Rowley, MA: Newbury House.

Gardner, R. C., \& MacIntyre, P. D. (1991). An instrumental motivation in language study: Who says it isn't effective? Studies in Second Language Acquisition, 13, 57-72.

Green, A. (2007). IELTS washback in context: Preparation for academic writing in higher education. Cambridge University Press.

Harlen, W., \& Crick, R. D. (2003). Testing and motivation for learning. Assessment in Education, 10 (2), 169-207.

Hawkey, R. (2006). Impact theory and practice: Studies of the IELTS test and Progetto Lingue 2000. Cambridge University Press.

Hayes, B., \& Read, J. (2004). IELTS test preparation in New Zealand: Preparing students for the IELTS academic module. In L. W. Cheng, Y. Watanabe \& A. Curtis (Eds.), Washback in language testing: Research contexts and methods (pp. 97-111). Mahwah, NJ: Lawrence Erlbaum.

IIBC. (2005). TOEIC Newsletter \#89. Tokyo: International Business Communication. Retrieved from http://www.toeic.or.jp/toeic en/pdf/newsletter/newsletterdigest89.pdf

Klein, S. P., Hamilton, L. S., McCaffrey, D. F., \& Stecher, B. M. (2000). What do test scores in Texas tell us? Education Policy Analysis Archives, 8 (49). 1-22. Retrieved from http:// epaa.asu.edu/epaa/v8n49/

Lam, H. P. (1994). Methodology washback - an insider's view. Bringing about change in language education: Proceedings of the International Language in Education Conference 1994 (pp. 83-102). Hong Kong: Department of Curriculum Studies, Hong Kong University.

Lewkowicz, J., \& Zawadowska-Kittel, E. (2008). Impact of the new school-leaving exam of English in Poland. Research Notes, 34, 27-31.

Messick, S. (1989). Validity. In R. Linn (Ed.), Educational measurement (3rd ed.) (pp. 13-103). New York: Macmillan.

Messick, S. (1996). Validity and washback in language testing. Language Testing, 13(3), 241-256. doi: 10.1177/026553229601300302.

Nisbett, R. E. \& Wilson, T. D. (1977). Telling more than we can know: Verbal reports on mental processes. Psychological Review, 84, 231-259.

Popham, W. J. (1987). The merits of measurement-driven instruction. Phi Delta Kappa, 68, $679-682$.

Poret, A. (2007). English language learning in New Caledonia: A report on the proficiency achievements and motivation of students at or near the point of entry to tertiary study. 
He Puna Korero: Journal of Maori and Pacific Development, 8(1), 61-86.

Qi, L. (2004). Has a high-stakes test produced the intended changes? In L. Ceng, Y. Watanabe \& A. Curtis (Eds.), Washback in language testing: Research contexts and methods (pp. 147-170). Mahwah, NJ: Lawrence Erlbaum.

Qi, L. (2005). Stakeholders' conflicting aims undermine the washback function of a highstakes test. Language Testing, 22 (2), 142-173. doi: 10.1191/02655322051t300oa.

Qi, L. (2007). Is testing an efficient agent for pedagogical change? Examining the intended washback of the writing task in a high-stakes English test in China. Assessment in Education, 14 (1), 51-74. doi:10.1080/09695940701272856.

Saif, S. (1999). Theoretical and empirical considerations in investigating washback: A study of ESL/EFL learners. Unpublished doctoral dissertation, University of Victoria, Canada.

Saif, S. (2006). Aiming for positive washback: A Case study of international teaching assistants. Language Testing, 23 (1), 1-34. doi: 10.1191/02655322061t322oa.

Schmidt, C. (2004). The analysis of semi-structured interviews. In U. Flick, E.V. Kardoff \& I. Steinke (Eds.), A companion to qualitative research (pp. 253-258). London: Sage.

Schulte, D. P., Schulte, L., Slate, J. R., Brooks, G. D. (2002). A test-driven accountability system in Texas: Principals' voices. International Electronic Journal for Leadership in Learning, 6 (7) Retrieved from http://iejll.synergiesprairies.ca/iejll/index.php/ijll/ article/view/437/99

Shih, C. (2007). A new washback model of students' learning. The Canadian Modern Language Review, 64 (1), 135-162.

Shohamy, E. (1993). The power of tests: The impact of language tests on teaching and learning. NFLC Occasional Papers. Washington, DC: The National Foreign Center.

Shohamy, E. (2001a). The power of tests. Harlow: Pearson Education Limited.

Shohamy, E. (2001b). Democratic assessment as an alternative. Language Testing, 18 (4), 373-391. doi: 10.1177/026553220101800404.

Spratt, M. (2005). Washback and the classroom: The implications for teaching and learning of studies of washback from exams. Language Teaching Research, 9, 5-29. doi: 10.1191/13621688051r152oa.

Stoneman, B. W. H. (2006). The impact of an exit English test on Hong Kong undergraduates: A study investigation the effects of test status on students' test preparation behaviours. Doctoral dissertation, Hong Kong Polytechnic University, Hong Kong, China.

Taylor, L. (2005). Washback and impact. ELT Journal, 59(2), 154-155.

Valazza, G. (2008). Impact of TKT on language teachers and schools in Uruguay. Research Notes, 34, 21-26.

Wall, D. (2000). The impact of high-stakes testing on teaching and learning: Can this be predicted or controlled? System, 28, 499-509. doi: http://dx.doi.org/10.1016/ S0346-251X(00)00035-X.

Wall, D. (2005). The impact of high-stakes examinations on classroom teaching. Cambridge University Press.

Wall, D., \& Alderson, J. C. (1993). Examining washback: The Sri Lankan impact study. Language Testing, 10(1), 41-69. doi: 10.1177/026553229301000103.

Wall, D., \& Horak, T. (2006). The impact of changes in the TOEFL examination on teaching and learning in central and eastern Europe: Phase 1, the baseline study. Princeton, NJ: Educational Testing Service.

Wall, D., \& Horak, T. (2008). The impact of changes in the TOEFL examination on teaching and learning in Central and Eastern Europe: Phase 2, coping with change. Princeton, NJ: Educational Testing Service.

Watanabe, Y. (1996a). Does grammar translation come from the entrance examination? Preliminary findings from classroom-based research. Language Testing, 13 (3), 318-333. doi: $10.1177 / 026553229601300306$.

Watanabe, Y. (1996b). Investigating washback in Japanese EFL classrooms: Problems of methodology. In G. Wigglesworth \& C. Elder (Eds.), The language testing cycle: From inception to washback (Vol. 13) (pp. 208-239). Applied Linguistics Association of 


\section{Australia Series.}

Watanabe, Y. (2004a). Teacher factors mediating washback. In L. Cheng, Y. Watanabe \& A. Curtis (Eds.), Washback in language testing: Research contexts and methods (pp. 129-146). Mahwah, NJ: Lawrence Erlbaum Associates.

Watanabe, Y. (2004b). Methodology in washback studies. In L. Cheng, Y. Watanabe \& A. Curtis (Eds.), Washback in language testing: Research contexts and methods (pp. 19-36). Mahwah, NJ: Lawrence Erlbaum.

$\mathrm{Wu}$, J. (2008). Views of Taiwanese students and teachers on English language testing. Research Notes, 34, 6-9.

Yu, C. (2010) Reliability of self-report data. Retrieved from http://www.creative-wisdom.com/ teaching/WBI/memory.shtml

Yi-Ching Pan has a Ph.D. in Applied Linguistics from the University of Melbourne and is currently an Associate Professor at the National Pingtung Institute of Commerce in southern Taiwan. Since 2009 she has been on the editorial board of the International Journal of Educational and Psychological Assessment and in January 2011 she edited a special edition of that publication on foreign language assessment. Her research interests include second language acquisition, and language testing. yichingpan@yahoo.com.tw

Tim Newfields has a M.A. in TESOL from the School for International Training and has taught EFL in Japan and Taiwan since 1983. From 2000-2011 he edited the JALT Testing \& Evaluation SIG Newsletter and currently he edits RYUUGAKU: Explorations in Study Abroad. His research interests include assessment literacy, multicultural education, and CALL. 